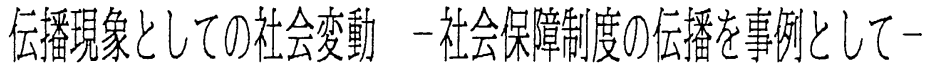

Social Change as Diffusion Phenomenon:

a case study of social security system

織田 輝哉

ODA Teruya

\begin{abstract}
Diffusion is an important concept in the individualistic social theory. Because, in this theory, social change is recognized as frequency transition of action strategies of individuals, and frequency transition is mediated by diffuison. Diffusion could happen among individuals, groups, and societies; we analyse establishment of social security system as a diffusion process of single action strategy among societies. Five social security services are analysed with regression analysis of logistic function. As a result, two services are proved to be in diffusion processes. To advance the study of diffusion process, frequency transition of plural action strategies in a game situation must be done.
\end{abstract}

\section{1. 個人主義的社会理論と伝播}

近年、理論社会学の領域において、個人の行為から社会理論を構成していくアプローチ が盛んになってきた。この「個人主義的社会理論」は、経済学や政治学の合理的選択モデ ルから多大な影響をうけている。特に、経済学的な行為モデルの、非経済現象（主として 政治）への適用としての公共選択論は、それがさらに社会学にも拡大される可能性を示し たものとして、影響が大きい。合理的選択を核とした個人主義的社会理論は広い適用の可 能性を持つもつものといえよう。Hindessは合理的選択論の社会理論への応用をポートフォ リオモデルという概念でくくって批判的な視座から捉えているが (Hindess 1988)、これ も個人主義的社会理論の拡大を物語っているものといえよう。

だが、個人主義的社会理論が社会学理論として確立していくために避けて通れないのは、 「個人と社会」の問題である。方法論的「社会」主義の立場からいえば、社会現象は、個 人に分解し還元するということができないものであり、複数の個人が関与したときに現れ てくる「創発特性」こそが、社会学の研究対象である、ということになる。この立場から いえば、個人主義的社会理論は、個人行為を分析の対象とするために、「社会」の分析に は到達できないことになってしまう。個人行為からどのように社会が構成されているのか を示すことは、個人主義的行為理論の第 1 の課題である。そこで、重要な意哧を持ってく るのが、「伝播（diffusion）」なのである。以下では、伝播が社会変動論の中で持ってい る意味を検討し、さらに、全体社会レベルでの伝播による社会変動の事例として、社会保 障制度を取り上げて分析する。

社会保障研究所研究員 


\section{2. 個人主義的社会理論のモデル}

個人主義的社会理論とは、社会的「実体」を仮定することなく、個人の行為から、社会 現象を説明しようとする理論である。合理的選択モデルは、さらに、個人の行為について 目的を達成するための最適な行為の選択という意味での合理性を仮定し、また、個人間の 関係として、ゲーム的状況を検討する。だが、合理性の仮定は、必ずしも不可欠なもので はない。

ここで、伝播現象を検討するために最小限必要な理論的整理を行っておこう。行為を行 う単位は、各個人である。各個人は、全くランダムに行為するのではなく、ある場面にお いては、一定の行為選択肢の集合を持っており、状況に応じてこの中から一つを選び出し て行為する。場面とそこで可能な行為選択肢の集合、および状況に対する行為選択肢の選 択方法についての規則を合わせたものを、ここでは「行為戦略」と呼んでおくことにする。 (1)つまり、行為者は、自分がどういう場面にいるのかを認知し、そこで、環境、および他 者の行為から構成される状況を把握して、ルールに従って、手持ちの行為選択肢から一つ を選び出し、行為する。よって、行為者は、意味的に分節化した場面数と少なくとも同じ だけの行為戦略を持っていることになる。

ところで、行為戦略は複数存在する。同じ場面でも個人によって異なった行為戦略をと る場合がある。そこで、ある場面での行為戦略の社会全体での採用頻度を考えることがで きる。複数の個人が関与している場面で、行為者の合理性を仮定した場合、つまり、行為 選択のルールを、自己の効用を最大化する結果をもたらす行為を選択する、とした場合、 行為戦略を一定とすれば、場面每に、各行為者の行為選択は、ナッシュ均衡になっている と考えられる。だが、行為戦略自体も選択の対象であり、選択対象となりうる行為戦略集 合からの選択についても、何らかの形で均衡状態に達していると考えられよう。行為戦略 の変更は、行為選択レベルでの均衡を変化させ、また他者の行為戦略の変更を喚起すると いうように、動的な関係にあるとみることができる。だが、行為者が合理的に行為してい るということは不可欠の仮定ではない。ここでは、行為選択・および行為戦略の選択があ る基準で行われており、ある程度安定した行為パターンができている状況を想定すること で十分である。

社会変動を考える場合には、一定の行為選択肢および選択のルール（つまり行為戦略） を前提とした上での選択肢の出現頻度の变化と、行為戦略自体の探用頻度の变化とを分け て考えなくてはいけない。前者は、行為者以外の環境が独立に変化することによる場合（ 例 : 気温の上昇による掵房の使用の増加）と、行為者が環境に影響を与えて変化させ、そ れが行為者にフィードバックする場合（例：生産力の上昇による消費パターンの変化）と がある。一方、行為戦略自体の探用頻度が変化する場合は、選択肢は変化しないが選択の ルールが変化する場合と、選択肢自体を含めて行為戦略全体が変化する場合がある。

広義の社会变動は、一定の選択肢の中での出現頻度の変化と行為戦略の採用頻度の変化 の双方を含む概念である。つまり、行為者は以前と同じルールで行為しているが、環境の 变化により、選択が受動的に变ってきている、という場合もこの広義の社会变動には含ま れるのである。一方、狭義の社会変動は、行為戦略の採用頻度の変化のみを指すものであ る。この行為頻度の操用頻度の変化は、生物レベルでの種の中の遺伝子頻度の変化と対応 
づけることができ、その意味で、社会レベルにおける進化とも呼ぶことができる。(2)広義 の社会変動と狭義の社会変動は、また、水準変動と構造変動という概念（富永 1981:3） とも関連付けられる。つまり、狭義の社会変動は構造変動と対応し、広義の社会変動から 狭義の社会変動を除いたものが水準変動となる。

\section{3. 社会変動と伝播}

社会変動を行為戦略の採用頻度の変化ととらえる場合、これがどのようなメカニズムに よって起こるのかということが問題である。生物進化の場合、遺伝子頻度は、生殖と自然 淘汰によって変化していく。これに対して、行為戦略の場合、個人は自ら新しいものを工 夫して生み出すか、または他者の行為戦略を模倣することによって、行為戦略を変える。 これを全体としてみれば、新しい行為戦略をある個人が発明し、それが他の個人へと拡大 していくという過程である。これが、行為戦略の伝播（diffusion）である。

伝播現象の研究は、これまで主に、技術的なものの伝播に焦点が置かれてきた。例えば、 新しい農業技術を農家がいかに早く採用するか、新商品を消費者が買うようになるか、新 しい医薬品を医者が使うようになるか、ということが研究の主要な関心であった (Rogers 1983=1990:第 2 章）。この場合、新しい技術を使う効用のようなものは考えられているが、 新しい技術を採用した個人間の相互行為のようなものは視野に入らない。例えばRogersは 革新の伝播のプロセスとして次のような 5 段階を考える。すなわち、(1)意志決定者が革新 についての知識を得る段階、(2)革新に対して好意的・非好意的な態度を決定する段階、(3) 革新の採用・非採用を決定する段階、(4)採用した革新を使用する段階、そして最後に(5)す でに行った革新について確信を得る段階、である（Rogers 1982:238-240）。このモデルで は、基本的に革新についての知識の伝播にもつぱら関心が向けられている。これは、よい 技術をいかに早く広めるかという実践的な目標があるためであろう。ところで、技術の採 用も、ここでいう行為戦略の採用の一つと考えられる。よって、技術の伝播も、行為戦略 の頻度变化の一つの特殊ケースととらえられよう。もちろん、より一般的な行為戦略の伝 播は、ゲーム的状況での相互行為をも視野に入れるものであり、単純な技術の伝播よりも 複雑な現象を含むのである。

\section{4. 意志決定主体の多重性}

ここで、注意しておかなければならないのは、行為戦略の選択に関わる意志決定主体は 個人のみに限定されるものではないという点である。例えば、新しい産業技術を採用する 主体は、企業であるし、法や制度を採用するのは、国家である。したがって、個人レベル での行為戦略の採用を論じてきたここまでの議論は、より上位の意志決定主体にまで拡張 されなくてはいけない。

その場合、問題になるのは、個人主義的社会理論が仮定していない、社会的実体を意志 決定主体として設定してしまうことになるのではないか、ということである。これについ ては、次のように考えることによって、社会的実体の仮定を回避することができる。すな わち、ここでいう個人を超えた意志決定主体は、意志決定主体の側からみると、複数の個 
人もしくは集団による社会的決定過程を通じて、共通の意志決定を行うメカニズムを意味 し、また他者からこの意志決定主体を見る場合は、実際には実体は存在せず、個人の集合 なのであるが、これを行為の便宜上、一つの個人であるかのように仮定し（例えば法人） 個人の場合と同じようにこの集合に対しても意志決定能力を仮定し、行為する。これによ って、社会的な意味世界の中では、あたかも個人よりも上位の意志決定主体が存在するか のように見えるが、実際には、それはあくまで行為を円滑に進めるための方便であり、そ の意味では、これ自体が進化の過程で生み出されてきた行為戦略なのである。以後の議論 の中では、複数の個人からなる意志決定主体は、あくまで、以上のように規定された意味 での意志決定主体であるということが、前提とされる。

さて、この意味での意志決定主体はさまざま有り得るが、ここでは便宜上、「個人」の ほかに、企業組織や団体、学校などのような「集団」、国民国家のような「社会」を考え ておく。これらの間の関係は重層的である。先に述べたように、集団や社会は、それ自体 が進化した行為戦略であり、それが意志決定主体の側に立つて、行為戦略を選択するので あるから事態は複雑である。また、レベルを超えた伝播、例えば、企業で成功した組織の メカニズムを国家が模倣するという場合など、があり、一つのレベル内部での伝播のみを 考えていればよいというわけではない。

\section{5. 伝播現象の諸モテル}

以上論じてきたことからも分かる通り、行為戦略の伝播を考える際には、さまざまな行 為戦略を持った個人間の関係の分析、すなわちゲーム論的な分析と、ある行為戦略が他の 個人へ伝わっていく過程の分析の両方が必要である。だが、これまでの伝播現象の分析は、 新しい技術の伝播が中心だったこともあって、過程の分析がほとんどであった。行為戦略 のゲーム論的分析は、きわめて重要であるが、現時点では理論上の到達目標である。ここ では、一つの出発点として一般的な伝播現象の特殊ケースとして、ゲーム論的な状況にな い、一つの行為戦略のみについての伝播（ある新しい商品の購買行動などはその典型例で ある）を扱うこととしよう。(3)

このような形での伝播の分析は、さまざまな伝播現象について行われている。ここでそ れらをいくつかのパターンに分けて見てみよう。

\section{I ．個体差があることを仮定するモデル}

\section{A. 採用の時期に個体差があることを仮定するモデル}

これは、例えば、正規分布のような単峰型の分布を仮定し、これから採用者の累積度数 分布がS 字形になることを説明するもので、比較的初期に行われた (Pemberton 1936;193 7）。採用時点に個体差があるというモデルは、現実的なものだと思われるが、その後はあ まり、用いられていない。

\section{B．採用する探用率の䦭に個体差があることを仮定するモデル}

全体の採用率がどのくらいになった時に採用を決定するか、が個体によつて異なってい るというモデルである。Granovetterらは、これを用いて社会運動や消費行動の臨界点の分 析を行った (Granovetter 1978: Granovetter \& Soong 1983;1986)。すなわち、一定の普 
及率を越えると上限まで普及するという現象を、閤の分布形との関連で分析したのである。

\section{II．個体差を考えず、採用については確率的な現象とするモデル}

\section{A. 普及に上限を考えないモデル}

これは、普及に上限を考えず、既に採用した人の数に比例して採用者数が增加してい くモデルである。累積採用者数Yの増加率について、微分方程式の形でこれを示せば、

$$
\mathrm{d} Y / \mathrm{d} t=\mathrm{a} Y
$$

となり、これを解くと、

$$
\mathrm{Y}=\exp (\mathrm{a} t+\mathrm{c}) \quad(\mathrm{a}, \mathrm{c} \text { は定数 })
$$

となる。この場合、探用者数は、指数関数的に增加していく。

\section{B 普及に上限を考えるモデル}

(1) 未採用者が一定割合で採用するモデル

だが、採用者となる可能性のある主体の数には、一般にある上限がある。例えば、新製 品であれば、その製品の販売の対象となる市場にいる人の数（例えば全国民）が上限であ る。その場合、採用者数はどこかで頭打ちになることになる。そこで、非操用者の一定割 合が新たに採用するモデルを考えることができる。これは、微分方程式で次のよう表せる。

$$
\mathrm{d} Y / \mathrm{d} t=\mathrm{a}(\mathrm{k}-\mathrm{Y})
$$

これを解くと、

$$
\mathrm{Y}=\mathrm{k}-\mathrm{exp}(-\mathrm{at}+\mathrm{c})
$$

となる。ここで、 $\mathrm{k}$ が上限を表す。累積探用者数は初め急速に増加し、上限に近づくと頭 打ちになる。ここで、新しい行為戦略は、行為者間の相互作用というよりは、非採用者全 体に作用していると考えられるので、マスメディアモ゙デルと呼ばれる (Gray \& Broembsen 1974）のである。

（2）非採用者か、累積採用者数に応じて採用するというモテル

一方、可能な採用者数に上限を考えるのは同じだが、增加率に累積探用者数が影響を与 えるというモデルも考えられる。すなわち、累積採用者数に比例した割合の非採用者が新 たに採用する。この場合、初めはわずかづつしか增加しないが、累積採用者数が增えると 増加数も多くなり、やがて上限に近づくと頭打ちになるというS字形の採用者数のグラフ が描かれる。これは、微分方程式で表現すると次のようになる。

$$
d Y / d t=a Y(k-Y)
$$

これを解くと、

$$
\mathrm{Y}=1 /(\exp (-\mathrm{a}(\mathrm{t}-\mathrm{c}))+\mathrm{k})
$$

となる。これは、ロジスティック曲線である。これは、採用者が何らかの形で非採用者に 働きかけて採用を決断させるということを意味する。例えば、ランダムな相互作用を仮定 して、一定回数採用者と相互作用をすると採用を決定するというような状況を考えること ができよう。(4)その意味でこのモデルは相互作用モデルと呼ばれる（Gray \& Broembsen 1974)。

\section{(3) (1)と(2)の混合形態}

採用者数の上限があり、かつマスメディア効果と相互作用効果の両方がある場合であ る。これについては、Grayらが論じている（Gray＆ Broembsen 1974）。(1)と(2)を包摂 
するので、これはより一般的なモデルである。

(4) 增加率が、採用率の増加に伴って減少する効果を考えるモデル

以上のモデルで、採用者数が頭打ちになるのは、初めから採用者数に限界があるためで ある。だが、このモデルの場合、操用者数に限界を考えず、採用者数が増加していくこと 自体に、採用を押しとどめる効果がある場合を想定する。微分方程式ではこれは次のよう に表される。採用者の増加率は、累積採用者数に比例し、累積禁止数（採用を押しとどめ る効果をこう呼ぶ）に反比例するとすると、

$$
\mathrm{d} Y / \mathrm{d} t=(\mathrm{a} / \mathrm{i}) \mathrm{Y}
$$

ここで、累積禁止数iの增加率は累積禁止数に比例して、

$$
\mathrm{d} i / \mathrm{d} t=\mathrm{q} i
$$

となる。これを解くと

$$
i=i_{a} \exp (q t)
$$

ここで、i 。はt=0の時のi の值である。すると、初めの式から

$$
\mathrm{d} Y / \mathrm{d} t=\left(\mathrm{a} / \mathrm{i}_{\mathrm{b}}\right) \text { exp (-qt) } \mathrm{Y}
$$

となる。この微分方程式を解くと、ゴンペルス曲線（二重対数分布）になる。このモデル では、なんらかの形の「禁止」が存在し、この影響が時間的に指数関数的に増加していく ことが仮定されている。これによって、S字カーブをロジスティック曲線以外の形の関数 で説明しようとするわけである。Pitcherら（Pitcher et.al.1978）の分析の対象は、集 合的な暴力行為であり、「禁止」の意味が明らかなのだが、それ以外の伝播現象は「禁止」 という言葉は当てはまらない。Hamblinらは、「禁止」の代わりに、「廃棄」という言葉を 使っている（Hamblin et.al.1979）。これは、当該の行為戦略以外のより有効な行為戦略 が出てきたために採用者の増加率が低下することを意味しており、扱われている事例も、 交通手段やマスメディアである（例えば、馬の利用は車の登場により「廃棄」される）。 ゴンペルツ曲線の特徵は、ロジスティック曲線のように点対称ではなく、增加率の減少局 面はより緩やかである。

以上見てきたモデル以外にもさまざまなモデルを考えることができる。例えば、ここま でのモデルは一旦採用した人は、その行為戦略を放棄しないということを仮定していたが、 これを、採用した人が、放棄しうるモデルを考えることもできる（Witt 1989）。また、数 学的なモデル化においても、ここで示したような時間的に連続的なモデルとするか、ある いは離散時間を考えたモデルとするか、という選択がありうる。

次節では、このようなモデルの適用として、国家レベルの伝播現象である、社会保障制 度の伝播を取り上げよう。

\section{6. 伝播現象の実例 : 社会保障制度の伝播}

ここでは、上で述べた、個人・集団・社会の中の「社会」レベルでの行為戦略の伝播と して、社会保障制度の導入を取り上げる。社会保障制度（より一般的には福祉国家）は、 伝統的な社会においては家族や地域などによって担われてきた福祉機能が近代化によって 充足されなくなったり、近代化にともない新たなリスクが生じることに対応して、国家が 福祉機能を果たすようになるところから生まれてきたと考えられている。これまでの、例 
えばWilenskyの、社会保障の発展の分析においては、このような前提をもとに、ある国に おける産業化の進行度、核家族化、老齢化などの機能的必要性の度合を示す要因によって、 社会保障の費用や制度の導入を説明するという形を取ってきた。そして、その結果として 産業化の進行や福祉ニーズの高まりに伴い社会保障制度が発展するという結果が導かれた。 しかし、この分析は、制度があることを前提として、例えば社会保障費用が増大すること を説明するものであった。これは、論文前半での議論に沿っていえば、広義の社会変動で はあるが、狭義の社会変動ではない。つまり、同一の行為戦略に従って、機能的必要性の 変化に対応した結果が、費用の増大として現れてきているのであって、行為戦略自体を変 えたわけではないのである。したがって、狭義の社会変動を見るためには社会保障制度の 導入を見なければならないのであるが、これは費用の増大とは一応別のことと見る必要が ある。

一定の要件に達した時に制度を導入するというモデルを先行要件モデルとよぶことがで きるが、社会保障制度の操用について、先行要件モデルと伝播モデルの比較を行った論文 として、CollierとMessickのものがある（Collier \& Messick 1975）。先行要件モデルに 従えば、ある一定の産業化レベルに達したときに、各国は社会保障制度を採用するはずで ある。そこで、最初の社会保障制度を導入した年と、産業化の指標（農業労働力比率等） を用いて、散布図を作成すると、社会保障を導入する一定の産業化水準のようなものはな く、採用年が後になればなるほど、産業化が低い段階で社会保障制度を導入しているとい う結果が得られた。より詳細にいえば、ヨーロッパの初期操用者の中では、産業化の遅れ た国ほど早く採用し、中期採用者の中では特に産業化のレベルとは関連せず空間的に伝播 が起こり、後期採用者の間では年代が遅くなればなるほど、低い産業化レベルで採用する。 のである。つまり、後から来た国ほど、早く導入する、という後発効果が見られるのであ る。ここから、彼らは、先行要件モデルのある程度の説明力は認めつつも、他の社会の模 倣を通じて制度が成立するという伝播現象が政治変動の研究にとって重要であると結論づ けている。

制度の伝播ということについて、ほかにいくつかの先行研究がある。これらは、国の間 ではなく、アメリカの州の制度の採用を取り扱つたものである。アメリカの場合、州の権 限は大きく、広い範囲で法・制度を独自に制定できるようになっているため、このような 研究がなされるわけであるが、これも、一種の国レベルの制度の導入と見なせないことも ない。

州間の制度の伝播の分析に先鞭をつけたのはWalkerの研究である（Wa1ker 1969）。彼は、 州が新しい法・制度・政策を探用する早さを革新スコアとし、これを８８の法・制度・政 策について作成した。そこで彼が設定するのが、地域的㳊拋集団という概念である。州の 政策を決定する政治家は、不確実な情報に基づいて決定しなければならない。ここで他の 州での、ある制度の導入の有無・およびその結果についての情報は、不確実性を緩和し、 導入への障害を除くものと考えられる。この場合、全ての州が同じウエイトを持っている わけではなく、地理的に近接した州の影響が大きいはずだ、として設定されたのが地域的 準拠集団である。革新スコアについて因子分析を行つた結果、5つの地域梁拠集団が析出 された。これは、その地域準抛集団の中では、同じような制度が同じ位の早さで採用され ることを示している。(5) 
Walkerの分析では、伝播のメカニズムについては、具体的なモデルを提示していない。 Grayの研究（Gray 1973）では、さきに述べた相互作用モデル、すなわちロジスティック曲 線をモデルとして用いている。彼女はアメリカの各州の教育・福祉・公民権の三つの分野 の、12の法の採用について、ロジスティック曲線を累積採用数に当てはめる、回帰分析 を行った。すると、1 2 の法全てで、高い決定係数（0.9以上）が得られた。ただし、一次 式による回帰分析も有意であり、結局彼女は、約半数の法において、相互作用が重要な役 割をはたしていると結論づけたのである。また、彼女は、社会保障法のように、連邦レべ ルで立法が行われ、その後で州レベルでの立法が行われた場合は、S字曲線ではなく、初 めから急速に操用者数が增え、やがて $100 \%$ に漸近していくという形になることを指摘 している。これは、さきに述べたモデルの分類では、マスメディアモデルと対応関係にあ ると考えられよう。このように、単一の要因によって伝播が起こっているわけではないこ とは、WalkerとGrayの論文を取り上げて論じたEyestone（Eyestone 1977）によっても指摘 されているところである。

\section{7. 社会保障制度遒入のテー多分析}

では、各国の社会保障制度の導入について伝播モデルに従って分析を行ってみよう。こ こで取り上げる社会保障制度は、老齢年金・疾病保険・労災保障・失業保険・家族手当の 5 つである。

社会保障研究所のプロジェクト『社会保障発展パターンの国際比較』で作成されたデー タベースには、1 54 カ国の1965年〜1980年の社会保障費用・諸社会指標の他に、各制度 の導入年が入っている。これを用いてまず、各制度を採用した国の累積度数グラフを見て みよう。図1～図5の実線がそれである。これらを見ると、いずれも、まだ伝播の全過程 が終わっていないことが分かる。だが、一般的な傾向として、S 字型に近い形になってい ることは見て取れる。制度ごとに特徴を見ていくと次のようになる。

【老齢年金】初めは極めてわずかづつ増加する。今世紀に入つて徐々に増加率が高ま るが、急速な增加局面に入るのは第 2 次大戦後である。1980年でやや増加は緩やかになる。

【疾病保険】老齢年金に比べると初期の増加はやや急である。第 2 次世界大戦ご、極 めて急速に増加するが、その後増加率が鈍化し、ややゆがんだ形のS字になっている。

【労災保障】前 2 者と比べると全体的に増加は急である。比較的早い、第 1 次大戦中 頃から急速な増加局面が始まっている。1980年時点で、すでに増加率が低下した伝播の最 終局面に入っている。

【失業保険】1980年時点まででは、曲線というよりは直線である。だが、まだ探用国 数が少ないので、これから急速な普及が始まる可能性はある。

【家族手当】5つの制度の中では最も最近始まったものだが、初期から増加は急であ る。だが、1960年ごろからは、頭打ちもしくは横ばいの状態となっており、特異な形にな っている。

失業保険のようにまだ急速な增加局面に入っていないもの、家族手当のようにやや特殊 な普及過程をたどるものもあるが、残りの 3 制度については、比較的美しい $\mathrm{S}$ 字曲線を見 せている。CollierとMessickの研究からも先行要件モデルの説明力は限られていることが 
図 1 老龄年金の採用国数

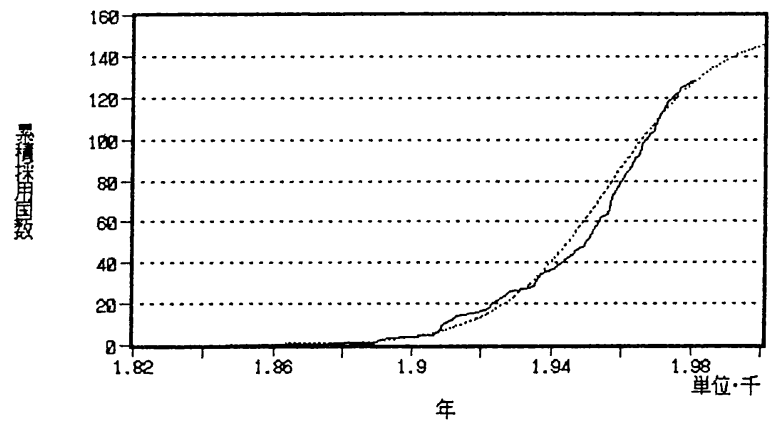

図 2 疾病保険の採用国数

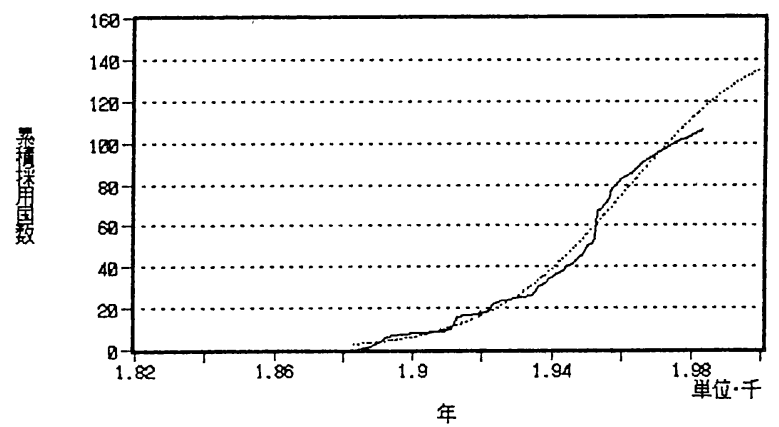

图 3 労炎保陪の採用国数

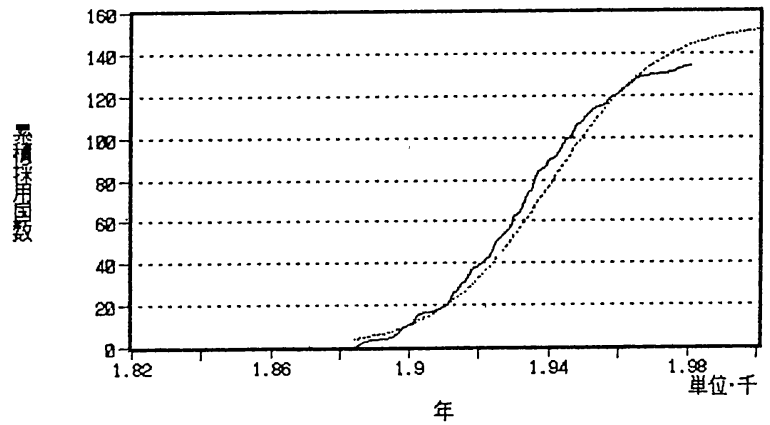

図 4 失菜保険の採用国数

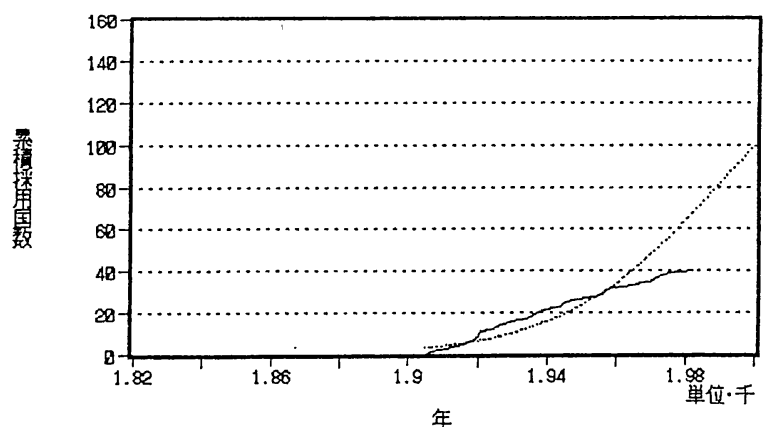


图 5 家护当の採用国数

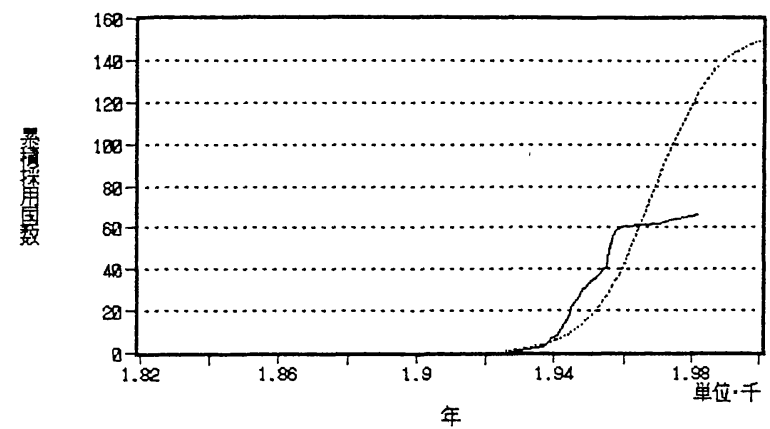

表 1 ロジスティック関数による回慢分析

\begin{tabular}{|c|c|c|c|}
\hline 制 度 & ロジスティック関数 & $R 2$ & 一次式の R 2 \\
\hline 老齡年金 & (採用国数 $)=1 /(\mathrm{exp}((1956-$ 年 $) / 15.58)+1)$ & 0.979 & 0.880 \\
\hline 疾病保険 & (採用国数) $=1 /(\mathrm{exp}((1961-$ 年 $) / 19.49)+1)$ & 0.978 & 0.904 \\
\hline 労災保障 & (採用国数 ) $=1 /(\mathrm{e} \times(\mid(1940-$ 年 $) /(15.42)+1)$ & 0.977 & 0.973 \\
\hline 失業保険 & (採用国数 $)=1 /(\mathrm{exp}((1987-$ 年 $) / 21.65)+1)$ & 0.843 & 0.989 \\
\hline 家族手当 & (採用国数) $=1 /(\mathrm{exp}((1969-$ 年 $) / 9.03)+1)$ & 0.850 & 0.927 \\
\hline
\end{tabular}

いずれも $1 \%$ 水準で有意

注）回㫜方程式は実際にはこの逆関数であるが、ロジスティック関数の形で示した。

分かっているので、これらについて伝播モデルを仮定し、ロジスティック曲線を当てはめ て、回帰分析を行ってみよう。これは、正確にいえば次のようになる。ロジステイック曲 線をそのまま通常の回帰分析に用いることはできない。非線型回帰分析のための、繰り返 し法を用いたパラーメーター推定を行わなくてはいけないのである。ここでは、その解析 手法が利用できないため、次のような方法を取った。まず普及の上限を $100 \%$ と仮定し た。次に、ロジスティック関数の逆関数を作り、これによって、年を採用国数に回帰させ た。その結果は表 1 のようになつた。また、この回帰曲線をプロットしたのが図 1 ～図 5 の点線のグラフである。

これによると、どの回帰方程式も有意であり、また決定係数もかなり高い。しかし、一 次式の回帰分析での決定係数もかなり高くなっている。ロジスティック関数の方が高い決 定係数を示しているのは、老齢年金・疾病保険・労災保障であり、失業保険・家族手当は むしろ線形回帰の方があてはまりがよい。特に失業保険の場合は、0.989ときわめて高い值 が出ている。また、労災保障についても、線形回帰でもかなり高い決定係数である。よつ て、以上の結果から、全ての国が伝播の対象となるような相互作用による伝播過程と見な しうるのは、老齢年金と疾病保険であり、労災保障の場合には、相互作用による伝播であ る可能性は否定できないが、毎年一定数の国が採用するという過程である可能性があり、 また、失業保険および家族手当については、全ての国が対象となる伝播過程と見なすのは 難しい。特に、家族手当は、普及の上限がかなり低い（普遍性がない）可能性がある。失 
業保険については、採用国数が少ないこともあり、伝播過程の初期段階である可能性もあ る。失業保険の場合は、採用率が $50 \%$ になるのが1987年と推定されるからである。

\section{8. 結果の解釈}

このように、社会保障制度の一部では、相互作用による伝播によって導入が行われてい ることが明らかになった。このような相亘作用による普及は、例えば次のようなモデルに よって説明される。新しい制度を導入する場合、政府が合理的であれば、制度の導入によ る便益とそれにともなう費用を考慮し、決定するであろう。便益は、導入した制度からの サービス供給による福祉ニーズの充足を通じた、政府への支持であり、費用は、制度の運 営に必要な費用負担を通じた支持の減少、および、新しい制度を入れるリスク（その制度 自体がうまく㗢くか、意図せざる結果がどうなるか、等）である。社会発展の水準はニー ズの量に影響を及ぼすが、採用国の比率も、国民の欲求水準の上昇をもたらす。一方、導 入のリスクは、他の国の採用実施状況を知ることで、不確実性を減少させることができる から、探用国の比率に対応して減少する。かくして累積採用国数は採用率に影響する。

ただし、社会保障制度を単純に伝播現象としてみることは危険である。というのは、以 上の結果は、社会保障制度の伝播というよりはむしろ、近代的な国民国家の伝播として見 ることもできるからである。その場合、社会保障制度は、近代的な国家制度の一部として 伝播することになる。先進国においては福祉国家を構成する諸要素が歷史的な試行錯誤を 経て完成してきたのに対して、後発国においては、後発性の利益として、これらがワンセ ットとして、導入される傾向がある。そのため、国家の独立と同時に社会保障制度が導入 される場合を考えればわかるように、産業化の水準が低い段階で導入されるということが 起こるとも考えられるのである。もちろんこれも伝播ではあるが、既に諸国家が成立した 状態である制度が伝播していくということとは性質を異にしている。実際、途上国が社会 保障制度を導入する場合は、国際的な体面、旧宗主国の影響等の要因が大きいことが平石 （平石 1985）によって指摘されている。

\section{9. 最後に}

以上、伝播現象の一つの事例として社会保障制度の導入を取り上げた。だが、先に述べ たように、このように単一の行為戦略が他者とのゲーム的な状況にならずに伝播していく というケースは、特殊ケースである。実際には、相互に代替的な関係にある行為戦略は複 数あり、これらの中からどれを選ぶかということが、重要な問題である。したがって、さ らに研究を進めていく場合、まず、ある行為戦略を採った時の利得の大きさとそれによる 採用確率の差異を考慮すること、次に複数行為戦略間の相対的な有利性による選択のメカ ニズムを考えること、さらに異なった（同じでもいい）行為戦略間のゲーム論的状況を考 慮した利得構造および探用の過程を分析すること、という段階が考えられる。その意味で は、社会変動の伝播現象としての分析はまだ緒についたばかりであり、より一般性の高い 理論を目指して概念・モデルの整備を行なう必要がある。 
（注１）これは通常ゲーム理論でいう戦略とは異なり、むしろメ夕戦略に当たるものであ るので注意が必要である。メ夕戦略については鈴村（鈴村 1982:57-63）の䇈論を参 照のこと。

（注 2 ）社会生物学においては、社会的行動は基本的に遺伝子レベルでの進化によって説 明されるが、ここでは遺伝子レベルとは異なった社会レベルでの進化を考え、二つ の進化の同型性を重視するものである。

(注3) ゲーム的状況における、行為戦略の探用頻度の変化を秩序問題との関わりで取り 上げたものとしては、拙稿（鐡田 1990）を参照されたい

(注4)これを空間的に表現して、コンピューターでモンテカルロ法によりシミュレーシ ヨンした研究もある (Hagerstrand 1965)。

（注 5 ）藤村（藤村 1987）は、社会保障制度の伝播に当たつて、「準拋国家」の重要性を 指摘している。

\section{【文献】}

Collier,D. \& Messick, R.E. 1975 "Prerequisites versus diffusion: testing alternative explanations of social security adoption", American Political Science Review 69(4):1299-1315

Eyestone, R. 1977 "Confusion diffusion, and innovation", American Political Science Review 71(2):441-447

藤村正之 1987 社会保障の国家間関係一準拋国家をめぐる一考察」『人文学報』194： 79-102

Granovetter,M. 1978 "Threshold models of collective behavior", American Journal of Sociology $83(6): 1420-1443$

Granovetter,M. \& Soong,R. 1983 "Threshold models of diffusion and collective behavior", Journal of Mathematical Sociology 9:165-179

Granovetter,M. \& Soong,R. 1986 "Threshold models of interpersonal effects in consumer demand", Journal of Economic Behavior and Organization 7:83-99

Gray,L.N. \& von Broembsen,M.H. 1974 "On simple stochastic diffusion models", Journal of Mathematical Sociology $3: 231-244$

Gray,V. 1973 "Innovation in the states: a diffusion study", American Political Science Review $67(4): 1174-1193$

Hagerstrand,T. 1965 "A monte carlo approach to diffusion", European Journal of Sociology $6(1): 43-67$

Hamblin,R.L., Miller,J.L.L., \& Saxton,D.E. 1979 "Modeling use diffusion", Social Forces 57(3):799-811

Hindes, B. 1988 Choice, Rationality, and Social Theory, Unwin Hyman, London

平石長久 1986 「途上国の社会保障制度一制度の導入を中心としてー」『海外社会保障情 報』70:25-33

織田輝哉 1990 「秩序問題への進化論的アブローチ」『理論と方法』5(1) 81-99 数理社 会学会

Pavalko,E.K. 1989 "State timing of policy adoption: workmen's compensation in the United States, 1909-1929", American Journal of Sociology 95(3):592-615

Pemberton,H.E. 1936 "The curve of culture diffusion rate", American Sociological Review 1:547-556

- 1937 "The effect of a social crisis on the curve of diffusion", American Sociological Review 2:55-61

Pitcher,B.L., Hamblin,R.L. \& Miller,J.L.L. 1978 "The diffusion of collective violence", American Sociological Review 43:23-35

Rogers,E.M. 1983 Diffusion of Innovation, 3rd Edition, The Free Press $=1990$ 青池慎一・宇野善隶監訳『イノベーション普及学』産能大学出版部

鈴村甈太郎 1982 『経済計画理論』第二版経済学全集 14 筑摩書房

富永健一 1981 社会変動の基礎理論」『基礎社会学：第 V 巻社会変動』 2-32

Walker,J.L. 1969 "The diffusion of innovation among the American States", American Political Science Review 63(3):880-899

Witt,U. 1989 "The evolution of economic institutions as a propagation process", Public Choice 62:155-172,1989 